\title{
What factors lead to poor pasture persistence and weed ingress?
}

\author{
K.N. TOZER ${ }^{1}$, G.W. BOURDÔT ${ }^{1}$ and G.R. EDWARDS ${ }^{2}$ \\ ${ }^{1}$ AgResearch, Ruakura Research Centre, Private Bag 3123, Hamilton 3240 \\ ${ }^{2}$ Lincoln University, PO Box 84, Lincoln 7647 \\ katherine.tozer@agresearch.co.nz
}

\begin{abstract}
In an ideal pasture, sown species would persist indefinitely and there would be no weeds. 'Poor persistence' occurs when the desirable species are replaced by weedy, undesirable species. Unfortunately, poor persistence of sown pasture plants is the reality that most farmers experience. In this paper we review the literature on three key factors leading to poor persistence and weed ingress: 1) inter-specific competition; 2) sward disturbance; and 3) propagule pressure. We reveal that grazing and other management decisions, pasture insect pests, nutrients, climate and the composition of the sown species mix have a critical influence on these factors, and hence over the replacement of sown pasture plants by weeds. The key practical message from this review is that farm practices that improve the vigour of sown species, reduce pasture gaps and minimise weed propagule pressure will improve the persistence of sown species and minimise weed ingress. An outstanding deficiency is our lack of knowledge of the economic impacts, and hence weed status, of most of the $c a 187$ volunteer plant species that may invade and replace sown plants in New Zealand's pastures.
\end{abstract}

\section{Introduction}

Poor persistence of sown pasture species and their replacement by weedy, less productive species is of concern to farmers. The cost of resowing a pasture is high and farmers have much to lose when sown species do not persist and weeds invade. In this paper, we review the New Zealand literature to document farmers' concerns regarding persistence and discuss the scientific evidence for poor pasture persistence and weed ingress. We then address three key factors that affect persistence (competition, disturbance and propagule pressure) and how these processes are affected by sown species mix, climate, nutrients, insect pests and grazing management.

Do farmers think pasture persistence is an issue? Persistence was ranked as the greatest limiting factor for pasture performance, followed by drought, in a recent survey of Bay of Plenty and Waikato dairy farmers (Kelly \& Smith 2010). Also, in a survey of
47 sheep, beef and dairy farmers from four regions in New Zealand (viz. Northland, Waikato, Taranaki and Canterbury), pasture persistence was consistently ranked as the highest research/information need in all regions (Tozer et al. 2011, this volume). Persistence is not a new issue, it was ranked as the fourth most important factor in the whole-farm system in a survey of 100 beef and sheep farmers in 1997/1998 (Daly et al. 1999).

\section{What is pasture persistence?}

Parsons et al. (2010) discussed how persistence can refer to a decline in the population of a sown species or the decline in the expression of a trait within the sown species present in the pasture. They also proposed that loss of persistence may be independent of the cultivars sown but related to a loss of the yield benefits that occur after pasture renewal. Previously, sheep and beef farmers identified persistent pastures as those containing a high level of desirable species and low levels of weeds which dominate in low-fertility conditions (Daly et al. 1999). Recently, 47 sheep, beef and dairy farmers in four New Zealand regions were interviewed to obtain their opinions on keys to persistence and factors causing the death of sown species. Many farmers expressed the view that sown species should be dominant in the sward of a persistent pasture, contributing significant dry matter for up to 10 or more years after sowing. In contrast, sown species in a poorly persisting pasture would only last for several years before undesirable weedy species became dominant (Tozer et al. 2011, this volume).

\section{What is a weed?}

Of the $c a 187$ species of pastoral weeds in New Zealand, nearly $25 \%$ are in the Asteraceae (daisy) family and $25 \%$ are grasses (Bourdôt et al. 2007). Harris (1970) listed eight reasons why a grass may be regarded as a pastoral weed. It may: (1) cause physical injury to livestock (e.g. Chilean needle grass (Nassella neesiana), barley grass (Hordeum spp.), ripgut brome (Bromus diandrus)); (2) lack palatability (e.g., nassella tussock (Nassella trichotoma), Eragrostis spp., ratstail (Sporobolus indicus)); (3) be poisonous (e.g., giant buttercup (Ranunculus acris); prussic acid in Sorghum 
spp. may rise to dangerous levels under certain conditions); (4) produce seeds that contaminate seed crops (e.g. wild oat (Avena fatua)); (5) provide poor herbage production (e.g. vulpia, Vulpia spp.); (6) die and leave an open sward (i.e. annual species such as Aira, vulpia, annual bromes (Bromus spp.) or annual poa (Рoa annua)); (7) fragment during cultivation and compete with establishing pasture species during pasture renewal (e.g. Indian doab (Cynodon dactylon) or kikuyu (Pennisetum clandestinum)); and (8) be a particularly aggressive grass that is capable of colonising a large area (e.g. Manchurian wild rice (Zizania latifolia), nassella tussock). Harris (1970) acknowledged that weeds that reduce livestock productivity may fulfil beneficial functions. For example, vulpia can provide fodder for stock or reduce erosion in dry hill country pastures that are unsuitable for perennial pasture species. Yet in a high producing pasture it provides little dry matter and is considered a weed. In contrast, nassella tussock would always be considered a weed, due to its aggressiveness, ability to suppress other species and poor feeding value. Reasons given for grasses being weedy can equally be applied to other types of weeds (e.g. shrubs, broad-leaved weeds.)

Another reason for labelling a plant as a weed is that it may reduce pasture production and its utilisation. For example, Wardle et al. (1994) found that growth and nitrogen fixation of white clover (Trifolium repens) in Waikato dairy pastures was suppressed in the vicinity of nodding thistle (Carduus nutans). This effect only occurred after the nodding thistle had produced a flower and its rosette leaves were decomposing and lasted for some months after the nodding thistle plant had died. In Waikato hill country pastures, nodding thistle and Scotch thistle (Cirsium vulgare) reduced forage utilisation, as livestock avoided foraging in the vicinity of the thistles (Seefeldt et al. 2005). Hartley \& James (1979) also found that California thistle (Cirsium arvense) impaired livestock access to forage, thus reducing pasture utilisation. Some weeds, however, can enhance pasture production; in Waikato dairy pastures, ragwort (Jacobea vulgaris) increased overall pasture production and stimulated perennial ryegrass (Lolium perenne) growth, even several months after the ragwort plant had died (Wardle et al. 1995).

Weeds are costly; it is estimated that the aggregate cost of pastoral weeds to the New Zealand economy is $\$ 1.2$ billion per annum, based on an analyses made in 1984 (Bourdôt et al. 2007). Individual weeds are also costly; for example, Bourdôt et al. (2003) estimated the national economic loss due to giant buttercup was NZ\$156 million over a 12-month period $(2000-2001)$.
What is the scientific evidence for poor pasture persistence and weed ingress being problems in New Zealand?

A search of the New Zealand literature, focusing on the New Zealand Grasslands Association Proceedings and publications from the New Zealand Plant Protection Society (formerly known as the New Zealand Weed and Pest Control Society), gave strong evidence that sown species are replaced by weeds. Rumball \& Grant (1972) analysed botanical composition data of pastures that were at least 3 years old, collected from 36 productive dairy and sheep farms (in Northland, Waikato, Bay of Plenty, Taranaki, Manawatu, Wairarapa and Nelson) by O'Connor \& Gregg (1971) and by Palmer (1970). On one-third of these farms, weeds comprised 40 to $48 \%$ of the total dry matter. Further, on some of these farms, Palmer (1970) found that volunteer grasses (mainly browntop (Agrostis capillaris), sweet vernal (Anthoxanthum odoratum), Yorkshire fog (Holcus lanatus) and Poa spp.) contributed over 20\% of the total pasture component in $76 \%$ of the perennial ryegrass-white clover pastures, ranging in age from 5 to 20 years old. These pastures were on dairy and sheep properties that were subject to better-than-average pasture management in the district. Palmer (1970) concluded that an indication of a weed's productive value and its impact on livestock and farm management would be valuable, given the prevalence of weeds in pastures. Yet today there remains a lack of information on the impact of weeds on dry matter production, intake and livestock performance.

More recently, a survey of 120 pastures by Tozer et al. (2010b) showed that there were declines in the contribution of sown species to total dry matter in Northland, North Canterbury and Waikato as pastures aged, while pastures in Taranaki were more stable, possibly because of the milder, wetter climate that was more amenable for perennial ryegrass growth.

Subtropical $\mathrm{C}_{4}$ grasses are also becoming more prevalent. They often have persistent seed banks and can spread vegetatively. Campbell et al. (1996, 1999) discussed how abundant summer rainfall, high temperatures $\left(>25^{\circ} \mathrm{C}\right)$ and factors reducing the vigour of temperate species (e.g. lower soil fertility and winter/ spring grazing damage) favour subtropical species such as summer grass (Digitaria sanguinalis) and paspalum (Paspalum spp.). The subtropical annual weed yellow bristle grass (Setaria pumila) is increasing in Waikato dairy pastures, especially after the recent and severe 2008-2009 drought when there was a large decline in perennial ryegrass content (Tozer et al. 2010c).

Madden (1962) gave a fascinating description of the botanical succession that takes place after bush is cleared and burnt for farming. He also discussed how the 
declining presence of sown species was reversed on two East Coast hill country properties in the North Island. This gives us insight into how weeds take over and how we may improve the persistence of sown species. The cleared land was sown to perennial ryegrass, cocksfoot (Dactylis glomerata), crested dogstail (Cynosurus cristatus) and white clover between 1920 and 1940. After the first 2 to 4 years, there was a decline in fertility and pastures deteriorated in quality and productivity. Sheet erosion further reduced fertility as the sward weakened and the pastures opened up and were invaded by fern, bidibidi (Acaena spp.) and less productive grasses and weeds. Grasses sown on secondary burns did not survive any longer than those sown on the primary burns and were replaced by danthonia (Rytidosperma spp.), sweet vernal, browntop, Yorkshire fog, hairgrass (vulpia?), moss, some small annual clovers and a variety of flatweeds. Ratstail, ricegrass (Microlaena avenacea) and lovegrass (Eragrostis curvula) were particularly prevalent on poor or dry places. Given this decline in pasture productivity, farmers reduced their sheep stocking rates by $25 \%$ and increased the number of cattle as more feed became available through more lenient grazing. Grazing management was modified to avoid continuous and selective grazing. Trampling and chewing by the cattle suppressed bracken (Pteridium esculentum), hardfern (Blechnum spp.) and shrubs. Over the following 20 years with the more lenient grazing pressure, productively superior species, such as perennial ryegrass, cocksfoot and clovers, became dominant (Madden 1962).

\section{How do weeds take over?}

We have given several examples documenting lack of persistence of sown species and ingress of weeds. There are three key factors that lead to weed ingress. The first is inter-specific competition, a process for which weeds seem better adapted than sown perennial species. The second is disturbance of the existing sward leading to canopy gap formation. The third is propagule pressure, which is often high in weeds. All three of these factors are affected by: (1) the characteristics of the sown species, (2) climatic/microclimatic conditions (water, light and temperature), (3) nutrients, (4) insect pests and (5) grazing management. In the following section we discuss, using examples from New Zealand literature, how the three factors influence weed ingress.

\section{How does inter-specific competition influence weed ingress?}

Competition has been defined by Begon et al. (1996) as 'an interaction between individuals, brought about by a shared requirement for a resource in limited supply and leading to a reduction in the survivorship, growth and/or reproduction of at least some of the competing individuals concerned'. If sown perennial species are unable to reduce the growth, survival and reproduction of weedy plants with which they interact, weed species are more likely to dominate.

Choice of pasture species is important because individual species vary in their growth requirements for light, water, space and nutrients. Availability of these resources influences competitive interactions with weeds. In 1996, a survey of beef and sheep pastures in the North Island showed that while cocksfoot tolerated low fertility, it responded well to high fertility, was more competitive and suppressed grasses such as browntop and sweet vernal, which grew best at lower fertility. However, at high fertility, cocksfoot also suppressed white clover and tall fescue (Schedonorus phoenix) (Festuca arundinacea) (Smith et al. 1998). Similarly, in Waikato hill pastures grazed by cattle, there was an increase in ryegrass and white clover content and decline in weedy grasses, such as browntop, in response to increasing phosphorus application (Ledgard \& Brier 1993).

In contrast to browntop, barley grass is an example of a weedy grass that can dominate areas of high fertility such as stock camps, which have high levels of soluble cations, salinity, nitrogen and phosphate (Grant \& Ball 1970; Palmer 1970). Other more desirable species are often unable to tolerate the high levels of salts found on stock camps, giving barley grass a competitive advantage in these situations. Additionally, barley grass and other annual grass weeds avoid heat and drought stress by producing seed which remains dormant over summer. This is in contrast to sown perennial species, which are often subject to drought, treading damage and overgrazing during this period.

Harris et al. (1977) stated that 'knowledge of the resident weed flora, their habitat preferences and the competitive characteristics of desirable crop and pasture species can lead to considerable weed control by sowing seed mixtures of specified composition and rate'. They tested a range of grass-legume mixtures (nine grasses, six legumes) and found that ryegrass cultivars reduced weed yield to a greater extent than prairie grass (Bromus willdenowii), timothy (Phleum pratense), cocksfoot and tall fescue. Ryegrasses were able to control weeds to about $5 \%$ of their potential yield. The competitive effect of legumes became more important as grass species became less competitive. Differences between species in their ability to suppress weeds was also demonstrated in the second year of a field trial at Palmerston North (Popay et al. 1981), where barley grass seedhead numbers were least in 
swards of Maru phalaris (Phalaris aquatica), followed by Nui perennial ryegrass, Roa tall fescue, Matua prairie grass and Ruanui perennial ryegrass. This ranking was similar at a second site in Hawke's Bay, with fewest heads in Maru phalaris, followed by Ellet perennial ryegrass, G17 cocksfoot, Nui perennial ryegrass, Roa tall fescue and Ruanui perennial ryegrass.

Location, management and climate all influence which mix will persist and suppress weeds. Some species are more drought tolerant than others. Tall fescue, cocksfoot and phalaris were used in mixtures in a drought recovery programme on the east coast of the North Island in 1990 and 1991, as the traditional perennial ryegrass/white clover mix was not persisting. Ninety-seven percent of the new pastures established well. This resulted in $112 \%$ more grazing and farmers reported greater animal production on the new pastures than the resident (mainly) perennial ryegrass-based pastures (Smith et al. 1998). Greater drought tolerance and vigour of cocksfoot in a dryland system may also explain why the establishment of vulpia and soft brome (Bromus hordeaceus) was lower in cocksfoot than perennial ryegrass pastures in Canterbury, which is subject to hot, dry summers (Tozer et al. 2010d).

Including a range of different species in a mix can ensure that space, water, nutrients and light are better utilised and that the weed is subjected to greater competition. This was demonstrated in dryland Canterbury, where oversowing annual legumes into a perennial grass/white clover pasture reduced survival and seed production of vulpia and soft brome (Tozer et al. 2010d).

There has been much research on frequency and intensity of grazing and its impact on botanical composition. From a series of 3-year experiments at the Marton Experimental Area in the 1950s grazed by sheep, MacLean (1958) drew several conclusions. He showed that longer spelling encouraged ryegrass and reduced Poa trivialis ingress while more frequent grazing encouraged white clover. However, a long spell of 6 weeks was also undesirable and encouraged an open sward and dock (Rumex spp.) ingress. Lax grazing can reduce ryegrass tiller density, which is why those pastures may have been prone to dock ingress (Hunt \& Easton 1989). MacLean's recommendation was to allow spelling of pastures between grazings so as to give growth of 4-6 inches in height, which encouraged growth of perennial ryegrass, timothy, cocksfoot, white clover and reduced the growth of Poa trivialis. Further, grazing should be carried out according to growth stage rather than a time interval - too soon or too long both have disadvantages. Chapman et al. (1984) studied ryegrass leaf longevity and death rates throughout the year under rotationally-grazed and set-stocked pastures to determine the impact on ryegrass recovery and growth. During autumn, spring and summer, leaf mortality occurred within 3 weeks of their appearance. Up to $28 \%$ of the leaves produced after one grazing died before the next grazing under the rotationally grazed system.

Hard grazing can favour $\mathrm{C}_{4}$ weed ingress in favourable climates at the expense of perennial ryegrass due to their different growth requirements and responses to grazing. Campbell et al. (1996) discussed how hard grazing in spring encouraged paspalum and hard cattle grazing in summer also resulted in ryegrass pulling and paspalum ingress. Paspalum ingress can occur through vegetative propagation as well as seedling establishment. During winter, pugging damaged the ryegrass tillers while paspalum was more tolerant to the pugging, giving it a competitive advantage.

\section{How does disturbance of the existing sward and canopy gap formation influence weed ingress?}

In addition to competition, disturbance and gap formation are critical for weed ingress to occur. Grime (1990) stated that disturbance 'is associated with the partial or total destruction of the plant biomass and arises from activities of herbivores, pathogens and humans (trampling, mowing, ploughing), and from phenomena such as wind-damage, frosting, droughting, soil erosion and fire'. Disturbance creates a 'gap', which Bullock (2000) defines as a competitor-free or plantfree space, which can vary in size from a single plant to many plants. By definition, a gap may occur above ground, or below ground in the root zone. Weedy plants are often better adapted than sown species to occupying these gaps due to characteristics such as aggressive growth, prolific seed production or ability to rapidly spread through vegetative means, as described by Harris (1970). In addition, the seedbank is often dominated by weed seeds rather than seeds of sown species (Tozer $e t$ al. 2010a). This gives weeds an advantage when gaps become available for occupation. In Waikato dairy pastures, Panetta \& Wardle (1992) found that most gaps occurred during January. In September (spring), January (summer) and April (autumn), 95\% of the gaps present were less than $10 \mathrm{~cm}$ in diameter.

Gaps are caused by a lack of persistence of sown plant species. A pasture with many gaps is commonly referred to as 'an open pasture'. Clue (1957) listed 10 ways in which a pasture can be opened up: (1) pugging in wet conditions; (2) trampling; (3) drought - causing sward death; (4) shading, as caused by shelter belts; (5) lack of fertility causing sward deterioration; (6) smothering (e.g. by dung deposition); (7) undergrazing - particularly if followed by overgrazing; (8) overgrazing; (9) insect attack; and (10) water logging. 
Clue (1957) concluded that only drought is totally outside the farmer's control if irrigation is not an option, although he commented that lax grazing can help to keep the soil cool.

Open pastures, leading to weed ingress, have been a critical issue since pastures were first sown during European settlement. Clue (1957) described how 'in the first Annual Report of the Department of Agriculture, in 1893 , there is a comment that "meadow fescue (Festuca pratensis) is one of the most widely-used grasses in the Colony."' Clue (1957) continued: 'Strangely enough it has never become naturalised and is at present one of the rarest grasses in the country.' He related this to the inability of meadow fescue to form dense swards under New Zealand conditions and concluded that it was a prime example of how an open sward leads to weed ingress.

The importance of drought in creating an open pasture was demonstrated by Round-Turner (1970), who monitored botanical composition of ryegrass pastures grazed by sheep in southern Otago. There was a severe drought in the fourth year of the 9-year trial and thereafter a significant decline in sown species' (ryegrass, white clover) productivity over time (from the fourth to ninth years). There was also ingress of weedy grasses (especially annual poa, $P$. trivialis, soft brome and browntop). Given that nutrient levels were adequate for growth, there were no major attacks of disease or insect pests and drainage was adequate, Round-Turner (1970) concluded that drought was the major contributing factor that initiated the decline in productive species and ingress of weedy grasses.

Conversely, pastures can be managed to maintain cover and persistence of sown plant species, while reducing weed ingress, although this may not always optimise livestock production. In a 6-year study on a ryegrass-white clover pasture grazed by sheep, Harris \& Brougham (1968) found that lax rotational grazing from $22-30 \mathrm{~cm}$ to a residual of $7-10 \mathrm{~cm}$ reduced ryegrass density and excluded browntop. However, while weeds were excluded, much available dry matter was wasted. Moderate grazing also resulted in an almost pure stand of ryegrass and white clover, while in contrast, browntop, Poa spp., horned oxalis (Oxalis corniculata), hydrocotyle (Hydrocotyle moschata), procumbent pearlwort (Sagina procumbens) and dandelion (Taraxacum officinale) invaded pastures that were continuously and closely grazed. Under close grazing, death of Italian ryegrass (L. multiflorum) $\mathrm{cv}$. Grasslands Manawa hastened the ingress of browntop, demonstrating how gaps allow weed establishment and contribute to poor pasture persistence.

Further evidence regarding the importance of disturbance/resource availability is supplied by Phung
\& Popay (1981), who compared swards trimmed weekly and maintained at $6-7 \mathrm{~cm}$ or $2-3 \mathrm{~cm}$ in height. When compared to bare ground, short vegetation reduced germination of nodding thistle, California thistle and ragwort, while long vegetation reduced germination of these species and additionally Scotch thistle, variegated thistle (Silybum marianum), giant buttercup (Ranunculus acris) and stinking mayweed (Anthemis cotula). Nodding thistle and giant buttercup germination was reduced by up to $90 \%$ in the long vegetation. Boswell \& Crawford (1978) found that grazing to $3 \mathrm{~cm}$ produced a denser sward than grazing to $6 \mathrm{~cm}$, although grazing below $3 \mathrm{~cm}$ reduced tiller density in dry conditions. In droughts, when feed is scarce, it is easy for pastures to be overgrazed, resulting in plant death and creating gaps for weed invasion.

Rotational and continuous grazing have different effects on gap creation. Edwards et al. (2005) compared the effect of rotational and continuous grazing on the establishment of desirable and weed species in pastures grazed by sheep. Initially, they found that weed seedling emergence in autumn was higher in rotationally grazed pastures, possibly because of more canopy gaps. However, as rotational grazing was continued through winter, weed seedling survival was reduced. They attributed this to light competition as pasture biomass accumulated during the recovery period between grazings and grazing defoliation of weed seedlings when swards were grazed. Edwards et al. (2005) concluded that the best strategy to reduce the ingress of weeds, such as Scotch thistle and broad-leaved dock (R. obtusifolius), was a combination of continuous and rotational grazing. This included continuous grazing in spring (when there was less bare ground than in rotationally grazed pastures) and rotational grazing during other times of the year (to reduce weed seedling survival).

Insect pest pressure can also reduce the vigour of sown species and contribute to their mortality, leading to gap formation. Endophyte can deter insects. It can also increase the vigour of the sown pasture species in which it resides and reduce weed ingress. Tozer et al. (2007a) found that AR542 endophyte infection of tall fescue in Canterbury dryland pastures helped to suppress barley grass cover and seedhead production. The impact of insect pests on pasture persistence has been covered in detail by Zydenbos et al. (2011, this volume) and will not be discussed further in this paper.

Herbicides can play a critical role in enabling sown species to establish. Browntop, Yorkshire fog and sweet vernal can often form a mat in infertile soils and make it difficult for perennial ryegrass and other species to establish (MacLean 1958). Herbicide application can kill the resident vegetation, leading to canopy and root 
gap creation, which enables the sown seed to establish. However, clovers can be damaged by herbicide applied to control weeds in established pastures, which can also open up the sward to weed ingress.

Differences between organic and conventional farming would be expected to result in differences in botanical composition and weed ingress. While conventional farmers can use herbicide to control weeds, organic farmers need to rely on other methods to reduce weed ingress. When one half of a Massey University dairy farm was converted to an organic system in 2001 and the other half remained conventional, there was no significant increase in weed cover in the organic system between 2003 and 2007 (Harrington et al. 2008). While the conventional system applied herbicide, the organic farm relied on grazing management to help control weeds. Harrington et al. (2008) suggested that the dense sward of perennial ryegrass, clovers, plantain (Plantago lanceolata) and chicory (Cichorium intybus) helped to prevent the ingress of weeds in established pastures within the organic system, although weeds were more difficult to manage during the establishment period as the herbicide MCPB could not be used. Hairy buttercup (Ranunculus sardous) and broad-leaved dock were dominant in both systems, but especially in new organic pastures.

\section{How does propagule pressure influence weed ingress?}

Martinez-Ghersa \& Ghersa (2006) stated that 'the invasive potential of a species can be assessed by propagule pressure, which measures the chances for propagules of a species to find a suitable habitat for establishment and reproduction.' Propagule pressure will depend on the frequency and quantity of propagules and the type of propagules present. Some species, such as yellow bristle grass, increase their propagule pressure by prolific seed production. Yellow bristle grass can produce over 100 seedheads per plant, with each seedhead containing 60-200 seeds (James et al. 2009). On Waikato dairy farms, new seedheads are rapidly produced between grazings, further increasing propagule pressure (Tozer \& Cameron 2009). While prolific seed production increases the chance of a weed's establishment, it is the fate of the seeds after dispersal which determines establishment success (Martinez-Ghersa \& Ghersa 2006). Weed propagules must occupy canopy gaps if the plants they give rise to are to establish and dominate a pasture.

Some weeds, such as Chilean needle grass, germinate when exposed to light and dark but will not germinate when kept in darkness, suggesting a gap-detecting mechanism (Bourdôt \& Hurrell 1992). A gap-detecting mechanism will enhance seedling establishment in pastures, which are environments of high competition.
Additionally, Chilean needle grass can germinate in both autumn and spring. It has a long-lived seedbank; $24 \%$ of seeds were viable when buried $2.5 \mathrm{~cm}$ below the soil surface after 6 years (Bourdôt \& Hurrell 1992). All these characteristics increase propagule pressure, leading to greater weed ingress and poorer persistence of sown species. Propagule pressure can also be exerted through vegetative spread. For example, giant buttercup colonises gaps in dairy pastures through rhizomatous growth as well as seed dispersal and germination (Lamoureaux \& Bourdôt 2007).

With more intensive farming, pastures are grazed so as to maintain optimal forage quality. Consequently, seed production in ryegrass and other sown species is reduced and as a result, these sown species become seed-limited, i.e. they have low propagule pressure. In a survey of 120 dairy, beef and sheep pastures, Tozer et al. (2010a) found that there was negligible carry-over of seed of sown species in the soil seedbank. In contrast, the seedbank was dominated by weedy broad-leaved and grass species (e.g. buttercup, annual poa, summer grass). Further, because of a lack of persistence, the cover of sown species tends to decline over time (e.g., Tozer et al. 2010c) and vegetative spread of existing sown species into gaps is insufficient to prevent a decline in sown species. Loss of plants will only leave gaps with unexploited moisture and nutrients, which will most likely be occupied by weeds which establish from the seedbank. One strategy may be to reduce grazing intensity in late spring to allow sown grasses and legumes to produce seeds and replenish the seedbank, thereby increasing their seedling recruitment.

Given the lack of persistence and lack of recruitment of sown species from the seedbank, pasture renewal is now common. Early stages of this renewal can have a big impact on pasture persistence. Smith et al. (1998) found that establishment success of sown species had long-term effects on tall fescue and cocksfoot persistence. They found that high levels of perennial ryegrass during establishment were associated with poor persistence of tall fescue and also possibly led to suppression of cocksfoot.

Seed companies recommend high sowing rates during pasture renewal to compensate for high seedling mortality due to a number of factors, make a sward more competitive and reduce weed ingress. This would lead to greater establishment and persistence of sown species. However, Armstrong et al. (2002) assessed the impact of sowing rates on seeds of Scotch thistle, nodding thistle and hedge mustard (Sisymbrium officinale) and found this not to be the case. They sowed the seeds into a perennial ryegrass swards that had been sown 12 months prior at rates of $5-80 \mathrm{~kg} / \mathrm{ha}$. While there was a non-linear increase in perennial ryegrass tiller density 
as the sowing rate increased, there was no effect of perennial ryegrass sowing rate on weed emergence and survival, indicating that the competitive ability of the pastures were the same at high and low plant densities.

Grazing management is a powerful tool for managing weeds by reducing their seed production. This is demonstrated by a survey of South Island high country properties, where less ripgut brome was present in hard than lax grazed sites (Tozer et al. 2007b). In this case, low grazing intensity allowed ripgut brome to produce seed.

\section{Conclusion}

Over fifty years ago, Saxby (1950) stated that 'permanent control of weeds in pastures involves two main phases. First, there is the removal or destruction of the (weed) plant, and second, there is the changing of the habitat conditions to such a degree that the weeds are unable to dominate again'. Clue (1957) added that 'weedkillers are of most value for controlling weeds in high-fertility pastures, provided measures are taken to remedy the weaknesses in the sward that allowed the weeds to ingress. In low-fertility pastures weedkillers are of much less value and the building up of sward thrift is the first consideration.' These principles remain the same today. Practices that improve the vigour of sown species and reduce pasture gap formation and weed propagule pressure will all reduce weed ingress. Examples of this would be judicious grazing of pastures during the establishment phase to minimise mortality of the sown species and provision of a stand-off pad to avoid pugging. In so doing they will also foster the persistence of sown pasture species.

While much research has been accomplished around the factors reviewed in this paper, there still remains a lack of information on the impact of weeds on pasture performance and livestock production and the direct effect of weeds on pasture persistence. An understanding of these factors would better equip us to improve the persistence of sown pasture species and hence also the long-term performance of our pastures.

\section{ACKNOWLEDGEMENTS}

Thanks to Sue Zydenbos and the external reviewers for valuable feedback on the manuscript.

\section{REFERENCES}

Armstrong, M.L.; Harrington, K.C.; Seefeldt, S.S. 2002. Weed establishment in the second year after high pasture sowing rates. New Zealand Plant Protection 55: 116-120.

Begon, M.; Harper, J.L.; Townsend, C.R. 1996. Ecology. Individuals, populations and communities. Blackwell Science Ltd., Oxford. 1068 pp.

Boswell, C.C.; Crawford, J.M. 1978. Changes in the perennial ryegrass component of grazed pastures. Proceedings of the New Zealand Grassland Association 40: 125-135.

Bourdôt, G.W.; Fowler, S.V.; Edwards, G.R.; Kriticos, D.J.; Kean, J.M.; Rahman, A.; Parsons, A.J. 2007. Pastoral weeds in New Zealand: status and potential solutions. New Zealand Journal of Agricultural Research 50: 139-161.

Bourdôt, G.W.; Hurrell, G.A. 1992. Aspects of the ecology of Stipa neesiana Trin. \& Rupr. seeds. New Zealand Journal of Agricultural Research 35: 101108.

Bourdôt, G.W.; Saville, D.J.; Crone, D. 2003. Dairy production revenue losses in New Zealand due to giant buttercup (Ranunculus acris). New Zealand Journal of Agricultural Research 46: 295-303.

Bullock, J.M. 2000. Gaps and seedling colonization. pp. 375-395. In: Seeds: the ecology of regeneration in plant communities. Ed. Fenner, M. CABI Publishing, Wallingford, Oxon, UK.

Campbell, B.D.; Mitchell, N.D.; Field, T.R.O. 1999. Climate profiles of temperate $\mathrm{C} 3$ and subtropical C4 species in New Zealand pastures. New Zealand Journal of Agricultural Research 42: 223-233.

Campbell, B.D.; Wardle, D.A.; Woods, P.W.; Field, T.R.O.; Williamson, D.Y.; Barker, G.M. 1996. Ecology of subtropical grasses in temperate pastures: an overview. Proceedings of the New Zealand Grassland Association 57: 189-197.

Chapman, D.F.; Clark, D.A.; Land, C.A.; Dymock, N. 1984. Leaf and tiller or stolon death of Lolium perenne, Agrostis spp., and Trifolium repens in setstocked and rotationally grazed hill pastures. New Zealand Journal of Agricultural Research 27: 303312.

Clue, D.I. 1957. Pasture management and weed control. Proceedings of the NZ Weed Control Conference 10: 29-33.

Daly, M.J.; Fraser, T.; Perkins, A.; Moffat, C.M. 1999. Farmer perceptions of reasons for perennial pasture persistence and the relationship of these with management practice, species composition, and soil fertility. Proceedings of the New Zealand Grassland Association 61: 9-15.

Edwards, G.R.; Hay, M.J.M.; Brock, J.L. 2005. Seedling recruitment dynamics of forage and weed species under continuous and rotational sheep grazing in a temperate New Zealand pasture. Grass and Forage Science 60: 186-199.

Grant, D.A.; Ball, P.R. 1970. Synecology of some barley grass communities in the central Manawatu. Proceedings of the NZ Weed and Pest Control Conference 23: 83-89.

Grime, J.P.; Hodgson, J.G.; Hunt, R. 1990. The abridged 
comparative plant ecology. Unwin Hyman, London, UK.

Harrington, K.C.; Osborne, M.A.; Kemp, P.D. 2008. Weed cover unaffected after converting a dairy farm to organic production. New Zealand Plant Protection 61: 116-120.

Harris, C.S. 1970. What is a "Grass Weed"? Proceedings of the NZ Weed and Pest Control Conference 23: 4750.

Harris, C.S.; Brougham, R.W. 1968. Some factors affecting change in botanical composition in a ryegrass-white clover pasture under continuous grazing. New Zealand Journal of Agricultural Research 11: 15-38.

Harris, W.; Henderson, J.D.; Gray, Y.S. 1977. The use of grasses and legumes for weed control in pastures. Proceedings of the NZ Weed and Pest Control Conference 30: 25-30.

Hartley, M.J.; James, T.K. 1979. Cost benefit of Californian thistle control in pasture. Proceedings of the NZ Weed and Pest Control Conference 32: 245249.

Hunt, W.F.; Easton, H.S. 1989. Fifty years of ryegrass research in New Zealand. Proceedings of the New Zealand Grassland Association 50: 1-23.

James, T.K.; Tozer, K.N.; Rahman, A. 2009. Yellow bristle grass: a recent weed incursion in Waikato dairy pastures. Proceedings of the New Zealand Grassland Association 71: 39-42.

Kelly, S.; Smith, E. 2010. Pasture renewal in the Waikato and Bay of Plenty regions AgResearch report prepared for DairyNZ. 21 pp.

Lamoureaux, S.L.; Bourdôt, G.W. 2007. A review of the ecology and management of Ranunculus acris subsp. acris in pasture. Weed Research 47: 461-471.

Ledgard, S.F.; Brier, G.J. 1993. Response to reapplication of phosphate fertilisers on hill pasture where fertiliser had been withheld for seven years. Proceedings of the New Zealand Grassland Association 55: 67-71.

MacLean, S.M. 1958. Effect of management on pasture composition. Proceedings of the New Zealand Grassland Association 20: 127-137.

Madden, E.A. 1962. The influence of cattle on pasture composition and second growth control. Proceedings of the New Zealand Grassland Association 24: 90-94.

Martinez-Ghersa, M.A.; Ghersa, C.M. 2006. The relationship of propagule pressure to invasion potential in plants. Euphytica 148: 87-96.

O'Connor, M.B.; Gregg, P.E.H. 1971. Nitrogen fertilizer trials on pastures. Proceedings of the New Zealand Grassland Association 33: 26-34.

Palmer, P.C. 1970. The presence of other grasses in perennial ryegrass/white clover pastures. Proceedings of the NZ Weed and Pest Control Conference 23: 5156.

Panetta, F.D.; Wardle, D.A. 1992. Gap size and regeneration in a New Zealand dairy pasture. Australian Journal of Ecology 17: 169-175.

Parsons, A.J.; Edwards, G.R; Newton, P.C.D.; Chapman, D.F.; Caradus, J.R.; Rasmussen, S.; Rowarth, J.S. 2010. Past lessons and future prospects: plant breeding for cool temperate pastures. pp. 272291. In: Proceedings of the 4th Australasian Dairy Science Symposium. Eds. Edwards, G.R.; Bryant, R.H. Christchurch, New Zealand.

Phung, H.T.; Popay, A.I. 1981. Effect of pasture cover on the germination of certain weed seeds. Proceedings of the NZ Weed and Pest Control Conference 34: 111113.

Popay, A.I.; Hartley, M.J.; Crouchley, G. 1981. The effect of different pasture cultivars on barley grass invasion Proceedings of the NZ Weed and Pest Control Conference 34: 107-110.

Round-Turner, N.L. 1970. The pattern of weed invasion in ryegrass pasture. Proceedings of the NZ Weed and Pest Control Conference 23: 57-65.

Rumball, P.J.; Grant, D.A. 1972. Weeds and the pasture community. Proceedings of the New Zealand Grassland Association 34: 91-98.

Saxby, S.H. 1950. Ecological aspects of weed control in pastures. Proceedings of the NZ National Weeds Conference 3: 51-55.

Seefeldt, S.; Stephens, J.; Verkaaik, M.; Rahman, A. 2005. Quantifying the impact of a weed in a perennial ryegrass (Lolium perenne) white clover (Trifolium repens) pasture. Weed Science 53: 113-120.

Smith, D.R.; Fraser, T.J.; Moffat, C.A.; Daly, M.J. 1998. Effects of soil fertility on the persistence of dryland cocksfoot and tall fescue pastures. Proceedings of the New Zealand Grassland Association 60: 265-270.

Tozer, K.N.; Barker, G.M.; Cameron, C.A.; James, T.K. 2010a. Relationship between seedbank and aboveground botanical composition during spring. New Zealand Plant Protection 63: 90-95.

Tozer, K.N.; Barker, G.M.; Cameron, C.A.; Loick, N. 2010b. New Zealand dryland pastures: effects of sown pasture species diversity on the ingress of unsown species. pp. 398-401. In: 17th Australasian Weeds Conference, Christchurch, New Zealand.

Tozer, K.N.; Cameron, C.A. 2009. Sweet success: Managing yellow bristle grass (Setaria pumila) with grazing attractants in dairy pastures. New Zealand Grassland Association 71: 43-47.

Tozer, K.N.; Cameron, C.A.; James, T.K. 2010. Yellow bristle grass spread in Waikato dairy pastures. pp. 351-354. In: Proceedings of the 4th Australasian Dairy Science Symposium, Christchurch, New Zealand. 
Tozer, K.N.; Cameron, C.A.; Thom, E.R. 2011. Pasture persistence: farmer observations and field measurements. Pasture Persistence. Grassland Research and Practice Series 15: 25-30.

Tozer, K.N.; Edwards, G.R.; Cameron, C.A. 2010d. Suppression of vulpia and goose grass in dryland pastures through the choice of sown pasture species. Proceedings of the New Zealand Grassland Association 72: 75-78.

Tozer, K.N.; Lucas, R.H.; Edwards, G.R. 2007a. Suppression of annual grass weeds by AR542 endophyte infection in dryland tall fescue pastures. New Zealand Plant Protection 60: 164-167.

Tozer, K.N.; Marshall,A.J.; Sedcole, J.R.; Edwards, G.R. 2007b. Ripgut brome (Bromus diandrus) distribution in relation to topography and management on seven high country properties in the South Island. New Zealand Plant Protection 60: 168-173.
Wardle, D.A.; Nicholson, K.S.; Ahmed, M.; Rahman, A. 1994. Interference effects of the invasive plant Carduus nutans L. against the nitrogen fixation ability of Trifolium repens L. Plant and Soil 163: 287-297.

Wardle, D.A.; Nicholson, K.S.; Rahman, A. 1995. Ecological effects of the invasive weed species Senecio jacobaea L. (ragwort) in a New Zealand pasture. Agriculture, Ecosystems \& Environment 56: 19-28.

Zydenbos, S.M.; Barratt, B.I.P.; Bell, N.L.; Ferguson, C.M.; Gerard, P.J.; McNeill, M.R.; Phillips, C.B.; Townsend, R.J.; Jackson, T.A. 2011. The impact of invertebrate pests on pasture persistence and their interrelationship with biotic and abiotic factors. Pasture Persistence. Grassland Research and Practice Series 15: 109-117. 
